\title{
2018 annual dialysis data report of the JSDT Renal Data Registry: patients with hepatitis
}

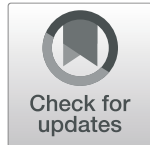

Kosaku Nitta', Shigeru Nakai ${ }^{1,2^{*}}$ (D, Ikuto Masakane ${ }^{1}$, Norio Hanafusa ${ }^{1}$, Shunsuke Goto ${ }^{1}$, Masatomo Taniguchi ${ }^{1}$, Takeshi Hasegawa” ${ }^{1}$ Atsushi Wada', Takayuki Hamano ${ }^{1}$, Junichi Hoshino ${ }^{1}$, Nobuhiko Joki ${ }^{1}$, Keichi Yamamoto ${ }^{1}$, Kenichiro Miura', Masanori Abe ${ }^{1}$, Hidetomo Nakamoto ${ }^{1}$ and on behalf of the Japanese Society for Dialysis Therapy Renal Data Registry Committee

\begin{abstract}
According to the annual survey of the Japanese Society for Dialysis Therapy Renal Data Registry (JRDR) conducted at the end of 2018, a total of 339,841 patients were receiving dialysis (hereinafter, dialysis patients) in Japan. This survey included an investigation of individual test results for hepatitis B surface antigen (HBsAg), hepatitis $C$ virus (HCV) antibody (HCV-Ab), HCV-RNA, and serum alanine aminotransferase (ALT) (glutamic pyruvic transaminase [GPT]). The survey revealed that among dialysis patients in Japan, the prevalence of HBsAg positivity was 1.38\% and the prevalence of HCV-Ab positivity was $4.7 \%$ at the end of 2018 , both of which were markedly lower than the corresponding rates documented in 2007 (9.8\% and 4.7\%, respectively). The proportion of HCV-RNA-positive patients among all HCV-Ab-positive patients was $37.5 \%$, which was also markedly lower than the percentage recorded in 2007 (64.0\%). The prevalence of HBsAg positivity tended to increase as the dialysis vintage increased. The prevalence of HCV-Ab positivity was also not correlated with the dialysis vintage during the first 30 years of dialysis; however, it tended to increase as the dialysis vintage increased beyond the 30th year.

Trial registration: University hospital Medical Information Network (UMIN) Clinical Trials Registry, UMIN000018641. The JRDR was approved by the ethics committee of the JSDT (approval number 1-3) and was registered on August 8, 2015 (accessed June 2, 2020).
\end{abstract}

Keywords: Dialysis, Registry, Hepatitis, Prevalence

\section{Introduction}

Since 1968, the Japanese Society for Dialysis Therapy (JSDT) has conducted a survey of the status of chronic dialysis treatment in Japan at the end of every year. This survey, known as the JSDT Renal Data Registry (JRDR), covers nearly all dialysis facilities throughout the country

\footnotetext{
* Correspondence: s-nakai@fujita-hu.ac.jp

'Japanese Society for Dialysis Therapy Renal Data Registry Committee, Japanese Society for Dialysis Therapy, Tokyo, Japan

${ }^{2}$ Faculty of Clinical Engineering Technology, Fujita Health University School of Health Sciences, Dengakugakubo 1-98, Kutsukake-cho, Toyoake, Aichi 470-1192, Japan
}

$[1,2]$. Although these facilities participate in the survey voluntarily, the response rate is nearly $100 \%$; consequently, this survey accurately represents the current status of regular dialysis in Japan. The 2018 JRDR survey contained several topics, such as the kinetics of chronic dialysis patients and dialysis facilities as of the end of 2018, water treatment and hemodiafiltration, peritoneal dialysis, treatments for diabetes, mental and physical conditions, and the present status of viral hepatitis. The present review paper is an English translation of the results, which were reported in Japanese, regarding the

(c) The Author(s). 2021 Open Access This article is licensed under a Creative Commons Attribution 4.0 International License, which permits use, sharing, adaptation, distribution and reproduction in any medium or format, as long as you give appropriate credit to the original author(s) and the source, provide a link to the Creative Commons licence, and indicate if changes were made. The images or other third party material in this article are included in the article's Creative Commons licence, unless indicated otherwise in a credit line to the material. If material is not included in the article's Creative Commons licence and your intended use is not permitted by statutory regulation or exceeds the permitted use, you will need to obtain permission directly from the copyright holder. To view a copy of this licence, visit http://creativecommons.org/licenses/by/4.0/ The Creative Commons Public Domain Dedication waiver (http://creativecommons.org/publicdomain/zero/1.0/) applies to the data made available in this article, unless otherwise stated in a credit line to the data. 
seroprevalences of hepatitis virus markers among dialysis patients obtained from the JRDR survey conducted at the end of 2018 and published in the Journal of the Japanese Society for Dialysis Therapy [3].

\section{Materials and methods}

JRDR consists of two surveys: a facility survey and a patient survey. The facility survey investigated details of the facility, such as the number of patients treated and the number of beds, while the patient survey investigated the patient backgrounds, such as the age and treatment method of individual patients treated at the facility. Spreadsheets created using spreadsheet software for personal computers were used for the surveys. Each patient was allocated one line of response space on the patient survey spreadsheet. Individual patient information was added to the spreadsheet by facility staff, rather than being answered directly by the individual patient.

The details of the survey of dialysis patients conducted in 2018 are available in a report describing the basic data of 2018 survey [4]. The survey included questions designed to investigate hepatitis-related items. The hepatitis B surface antigen ( $\mathrm{HBsAg}$ ), hepatitis $\mathrm{C}$ virus (HCV) antibody ( $\mathrm{HCV}-\mathrm{Ab})$, and $\mathrm{HCV}$ RNA statuses were investigated using the options shown in Table 1. These items were surveyed for all the patients included in this study. Information on the basic survey items was collected in the patient surveys from 327,336 patients. Among the patients whose information was available, 269,898 patients (82.5\%) provided information on their $\mathrm{HBsAg}$ status, 269,667 patients $(82.1 \%)$ provided information on their HCV-Ab status, and 91,334 patients (27.9\%) provided information on their HCV-RNA status. Valid information regarding a question on the serum alanine aminotransferase (ALT) level was collected from 281,331 patients $(85.9 \%)$.

The prevalence of positivity for each of the indicators was calculated using the equation shown below.

Prevalence of positivity $(\%)=$ Number of patients with a

positive test result $\div$ [number of patients with a positive test result + number of patients with a negative test result $] \times 100$

Table 1 Survey items and options used for hepatitis survey

\begin{tabular}{|c|c|c|}
\hline HBs antigen & HCV antibody & HCV-RNA \\
\hline $\begin{array}{l}\text { A. HBs antigen- } \\
\text { negative }\end{array}$ & $\begin{array}{l}\text { A. } \mathrm{HCV} \text { antibody- } \\
\text { negative }\end{array}$ & $\begin{array}{l}\text { A. HCV-RNA- } \\
\text { negative }\end{array}$ \\
\hline B. HBs antigen-positive & B. HCV antibody-positive & B. HCV-RNA-positive \\
\hline $\begin{array}{l}\text { Z. HBs antigen- } \\
\text { unknown }\end{array}$ & $\begin{array}{l}\text { Z. HCV antibody- } \\
\text { unknown }\end{array}$ & $\begin{array}{l}\text { Z. HCV-RNA- } \\
\text { unknown }\end{array}$ \\
\hline
\end{tabular}

The prevalences of $\mathrm{HBsAg}$ positivity and $\mathrm{HCV}-\mathrm{Ab}$ positivity were calculated for all the patients whose information for each item was valid.

In the trend analyses of these prevalences, exponential function regression was performed by plotting the prevalence of positivity among all dialysis patients recorded during each survey year along the $y$-axis and the year along the $x$-axis. The regression equation was determined using the least square method. JMP ver.15.2.0 (SAS Institute Inc.) was used as the analysis software.

\section{Results}

Trend in the prevalence of HBsAg positivity

Figure 1 graphically represents the changes over time in the prevalence of HBsAg positivity among all dialysis patients during the period from 1999 to 2018 [5-9] (Supplementary Table 1). The prevalence of $\mathrm{HBsAg}$ positivity remained almost unchanged at about 2\% from 1999 to 2007. During the interim period of 11 years between 2007 and the current survey conducted in 2018, the prevalence of HBsAg positivity decreased markedly to $1.38 \%$.

Figure 2 shows the results of an exponential function regression analysis, with the prevalence of positivity recorded at 5 time-points during the 1999-2007 period plotted along the $y$-axis and the year plotted along the $x$ axis. The prevalence of positivity in 2018 was 1.38\%, which was considerably lower than the rate predicted by the regression formula.

\section{Dialysis vintage and the prevalence of $\mathrm{HBsAg}$ positivity} Figure 3 shows the relationship between the dialysis vintage and the prevalence of $\mathrm{HBsAg}$ positivity in the current survey (Supplementary Table 2). The prevalence of HBsAg positivity was lowest (1.18\%) in the group of patients with a dialysis vintage of less than 2 years. The prevalence of positivity increased steadily as the dialysis vintage increased.

\section{Age and the prevalence of $\mathrm{HBsAg}$ positivity}

Table 2 shows the relationship between the patients' age and the prevalence of $\mathrm{HBsAg}$ positivity in the current survey. The prevalence of HBsAg positivity was highest between the ages of 60 and 74 .

\section{Treatment method and the prevalence of $\mathrm{HBsAg}$ positivity}

Table 3 shows the relationship between the patients' treatment methods and the prevalence of HBsAg positivity in the current survey. The prevalence of HBsAg positivity was highest among hemofiltration patients (10.00\%), followed by blood adsorption dialysis patients (2.91\%). The third highest prevalence of HBsAg positivity was among hemodialysis patients (1.48\%). The prevalence of HBsAg positivity among peritoneal dialysis patients 


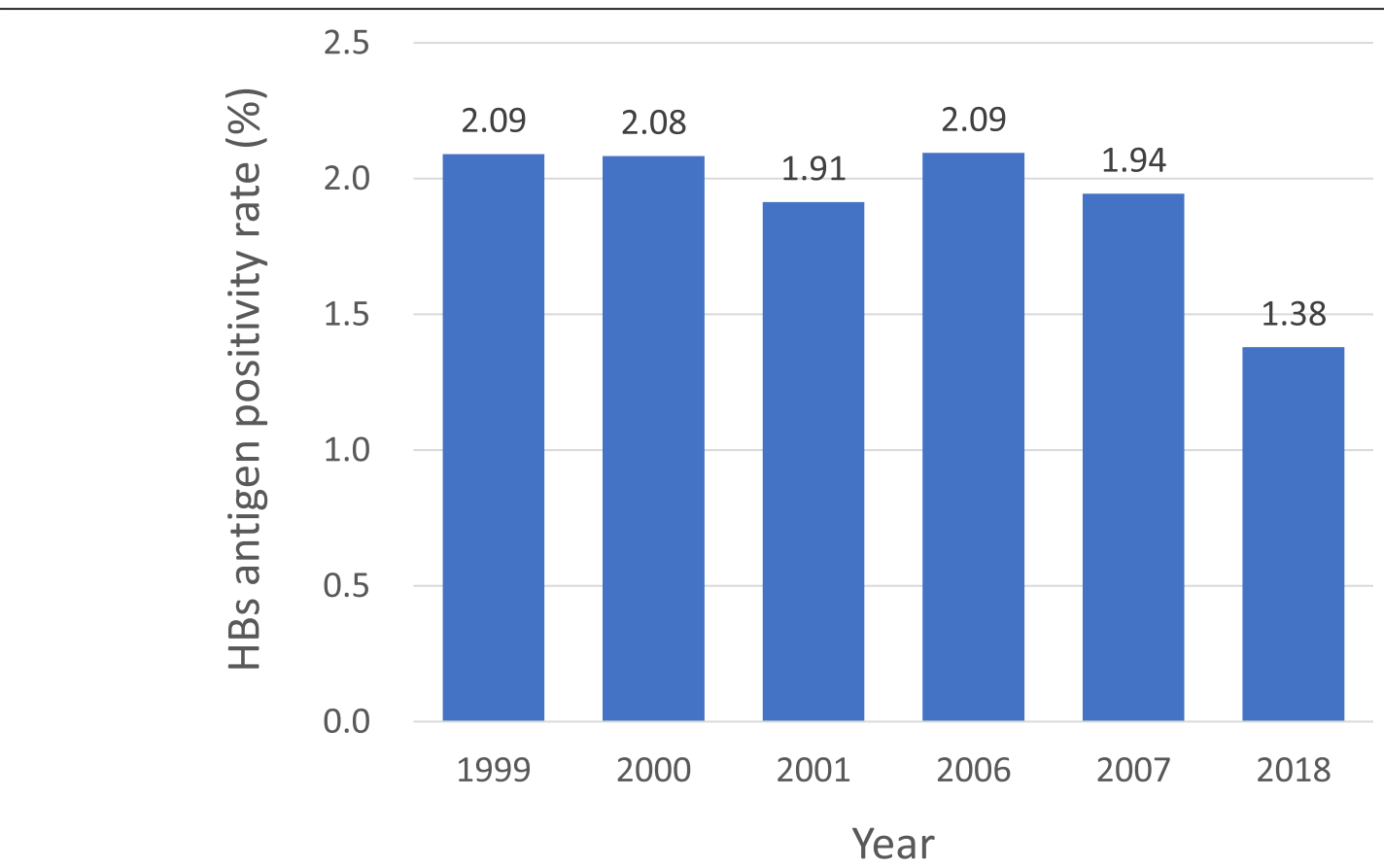

Fig. 1 Trend in the prevalence of HBs antigen positivity from 1999 to 2018 [5-9]. The data were obtained from the patient survey. HBsAg, hepatitis B surface antigen

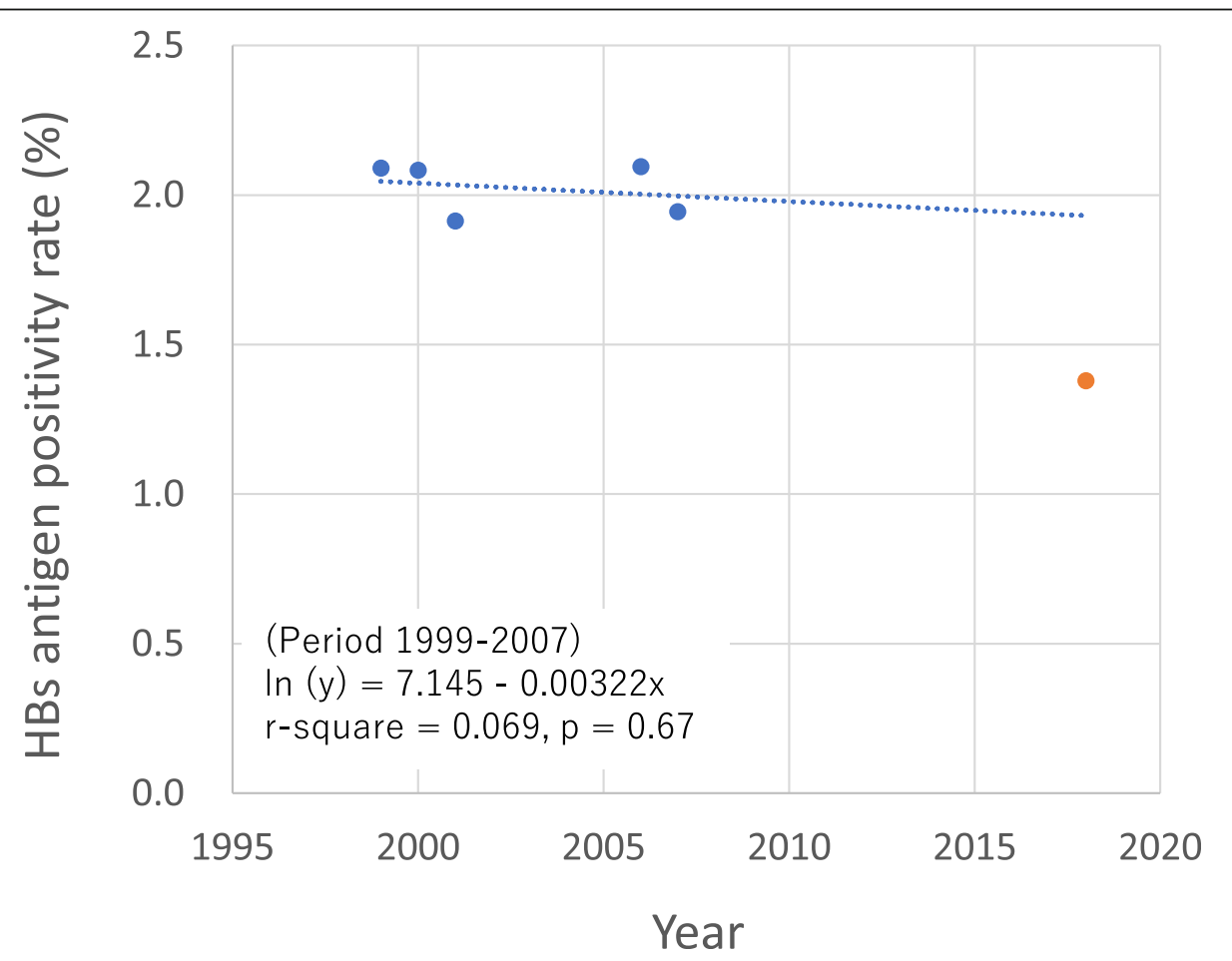

Fig. 2 Trend in the prevalence of HBs antigen positivity (results of a regression analysis) [5-9]. The data were obtained from the patient survey. HBsAg, hepatitis B surface antigen 


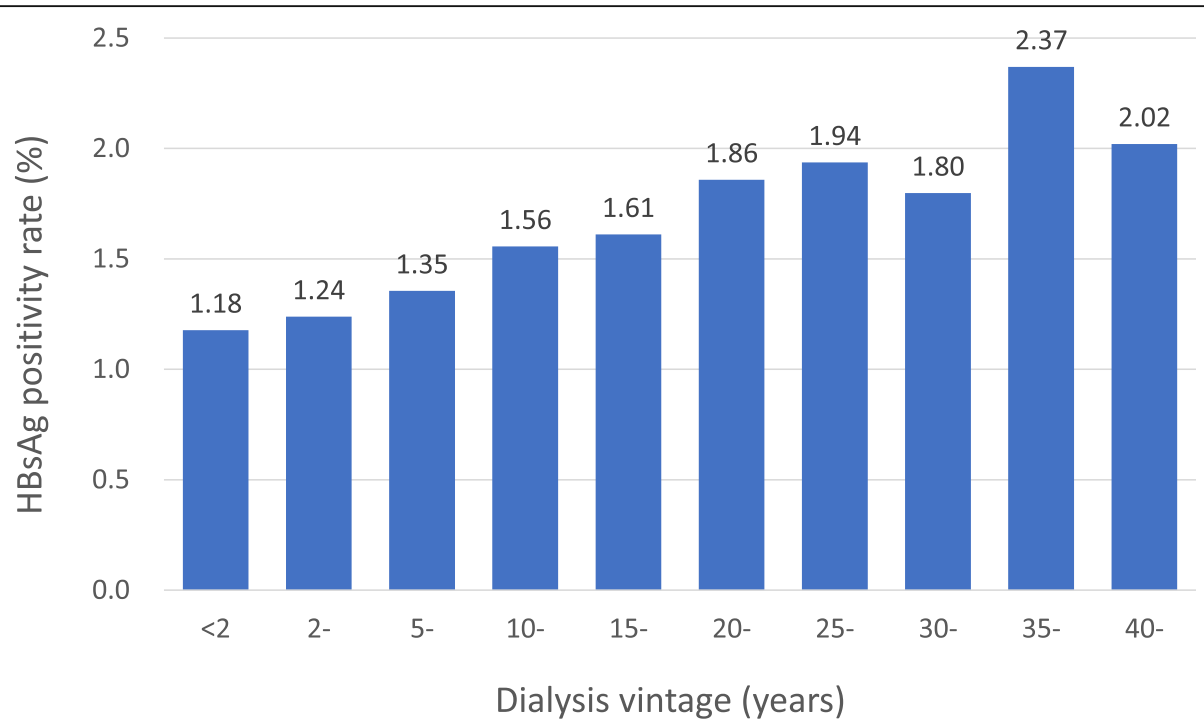

Fig. 3 Prevalence of HBs antigen positivity according to dialysis vintage as of the end of 2018. The data were obtained from the patient survey. HBsAg, hepatitis B surface antigen

(1.43\%) was slightly lower than that among hemodialysis patients. The prevalence of $\mathrm{HBsAg}$ positivity among hemodiafiltration patients $(1.20 \%)$ was lower than that among hemodialysis patients. The prevalence of HBsAg positivity among home hemodialysis patients (0.91\%) was the lowest, compared with those among patients undergoing the five other types of dialysis treatments.

\section{Trend in the prevalence of HCV-Ab positivity}

Under this survey program, HCV-Ab seroprevalence was first investigated in 1999. Thereafter, it was investigated every year from 1999 to 2003; HCV-Ab seroprevalence was not examined in 2004 and 2005, but it was once again included in the survey in 2006 and 2007 [1]. After 2007, the investigation was discontinued for 11 years, until it was resumed in the current survey. Figure 4 shows the changes in the prevalence of $\mathrm{HCV}-\mathrm{Ab}$ positivity during the 8 years for which data is available (1999 through 2003, 2006, 2007, and 2018) [5-11] (Supplementary Table 3).

The prevalence of $\mathrm{HCV}-\mathrm{Ab}$ positivity tended to decrease gradually from 1999 to 2007. In 2018, it was 4.7\%, which was markedly lower than the rate recorded in

Table 2 The prevalence of HBs antigen-positive patients sorted by their age, at the end of 2018

\begin{tabular}{|c|c|c|c|c|c|c|c|}
\hline $\begin{array}{l}\text { Age } \\
\text { (years old) }\end{array}$ & $\begin{array}{l}\text { HBs antigen- } \\
\text { negative }\end{array}$ & $\begin{array}{l}\text { HBs antigen- } \\
\text { positive }\end{array}$ & Subtotal & Unspecified & $\begin{array}{l}\text { No data } \\
\text { available }\end{array}$ & Total & $\begin{array}{l}\text { HBs antigen positivity } \\
\text { prevalence }(\%)\end{array}$ \\
\hline$<15$ & 47 & 0 & 47 & 11 & 30 & 88 & 0.00 \\
\hline $15 \leq,<30$ & 656 & 1 & 657 & 27 & 161 & 845 & 0.15 \\
\hline $30 \leq,<45$ & 9976 & 61 & 10,037 & 347 & 1761 & 12,145 & 0.61 \\
\hline $45 \leq,<60$ & 47,936 & 639 & 48,575 & 1768 & 8353 & 58,696 & 1.32 \\
\hline $60 \leq,<75$ & 113,627 & 1975 & 115,602 & 3984 & 20,249 & 139,835 & 1.71 \\
\hline $75 \leq,<90$ & 87,944 & 1003 & 88,947 & 3188 & 16,093 & 108,228 & 1.13 \\
\hline $90 \leq$ & 5990 & 43 & 6033 & 251 & 1215 & 7499 & 0.71 \\
\hline Subtotal & 266,176 & 3722 & 269,898 & 9576 & 47,862 & 327,336 & 1.38 \\
\hline Unspecified & 0 & 0 & 0 & 0 & 0 & 0 & \\
\hline No data available & 0 & 0 & 0 & 0 & 0 & 0 & \\
\hline Total & 266,176 & 3722 & 269,898 & 9576 & 47,862 & 327,336 & 1.38 \\
\hline Mean & 69 & 68 & 69 & 69 & 69 & 69 & \\
\hline S.D. ${ }^{a}$ & 12 & 11 & 12 & 13 & 13 & 13 & \\
\hline
\end{tabular}

The data were obtained from the patient survey

${ }^{\text {a }}$ Standard deviation

$H B$ s hepatitis B surface 
Table 3 The prevalence of HBs antigen-positive patients sorted by their treatment method, at the end of 2018

\begin{tabular}{|c|c|c|c|c|c|c|c|}
\hline Treatment method & $\begin{array}{l}\text { HBs: hepatitis B } \\
\text { surface }\end{array}$ & $\begin{array}{l}\text { HBs antigen- } \\
\text { positive }\end{array}$ & Subtotal & Unspecified & $\begin{array}{l}\text { No data } \\
\text { available }\end{array}$ & Total & $\begin{array}{l}\text { HBs antigen positivity } \\
\text { prevalence (\%) }\end{array}$ \\
\hline Hemodialysis & 158,700 & 2382 & 161,082 & 5,127 & 28,270 & $\begin{array}{l}194 \\
479\end{array}$ & 1.48 \\
\hline Hemodiafiltration & 99,864 & 1213 & 101,077 & 4,023 & 16,534 & $\begin{array}{l}121 \\
634\end{array}$ & 1.20 \\
\hline Hemofiltration & 9 & 1 & 10 & 0 & 2 & 12 & 10.00 \\
\hline $\begin{array}{l}\text { Blood adsorption } \\
\text { dialysis }\end{array}$ & 1202 & 36 & 1238 & 37 & 159 & 1434 & 2.91 \\
\hline Home hemodialysis & 544 & 5 & 549 & 15 & 144 & 708 & 0.91 \\
\hline Peritoneal dialysis & 5857 & 85 & 5942 & 374 & 2753 & 9069 & 1.43 \\
\hline Subtotal & 266,176 & 3722 & 269,898 & 9576 & 47,862 & $\begin{array}{l}327 \\
336\end{array}$ & 1.38 \\
\hline $\begin{array}{l}\text { Unspecified/no data } \\
\text { available }\end{array}$ & 0 & 0 & 0 & 0 & 0 & 0 & \\
\hline Total & 266,176 & 3722 & 269,898 & 9576 & 47,862 & $\begin{array}{l}327 \\
336\end{array}$ & 1.38 \\
\hline
\end{tabular}

The data were obtained from the patient survey $H B$ s hepatitis B surface

2007 (9.8\%). Figure 5 illustrates the results of an exponential function regression analysis, with the prevalence of $\mathrm{HCV}-\mathrm{Ab}$ positivity recorded at 7 time-points during the 1999-2007 period plotted along the $y$-axis and the year plotted along the $x$-axis. The prevalence of HCV-Ab positivity (4.7\%) in 2018 was approximately equal to the prevalence predicted by the regression formula.
Dialysis vintage and the prevalence of HCV-Ab positivity Figure 6 graphically represents the relationship between the dialysis vintage and the prevalence of $\mathrm{HCV}-\mathrm{Ab}$ positivity (Supplementary Table 4). Until a dialysis vintage of 25 years, the prevalence of $\mathrm{HCV}-\mathrm{Ab}$ positivity was almost constant at $4.0-4.7 \%$. However, at dialysis vintages of more than 25 years, the prevalence of $\mathrm{HCV}$-Ab positivity increased linearly as the dialysis vintage increased.

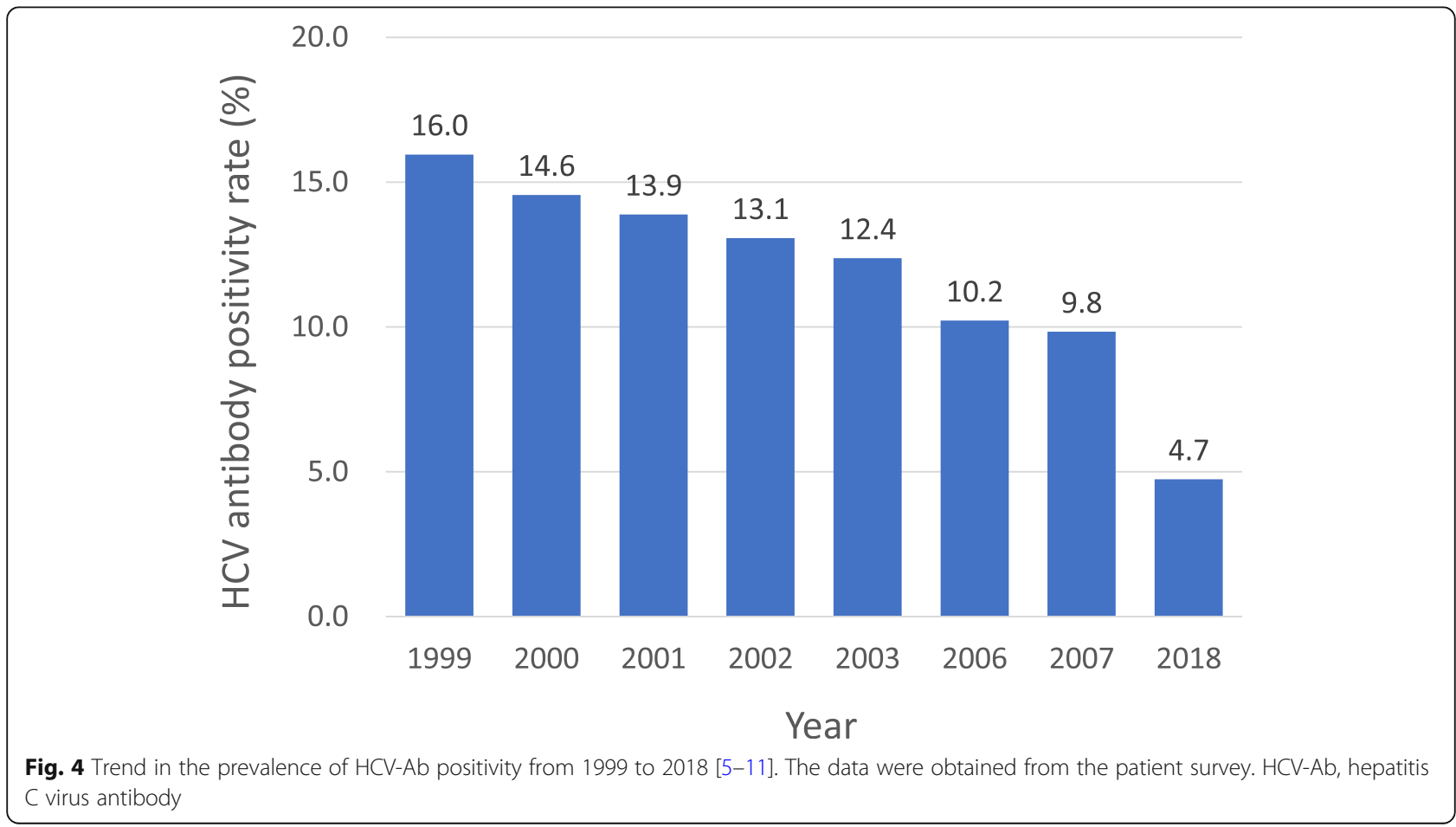




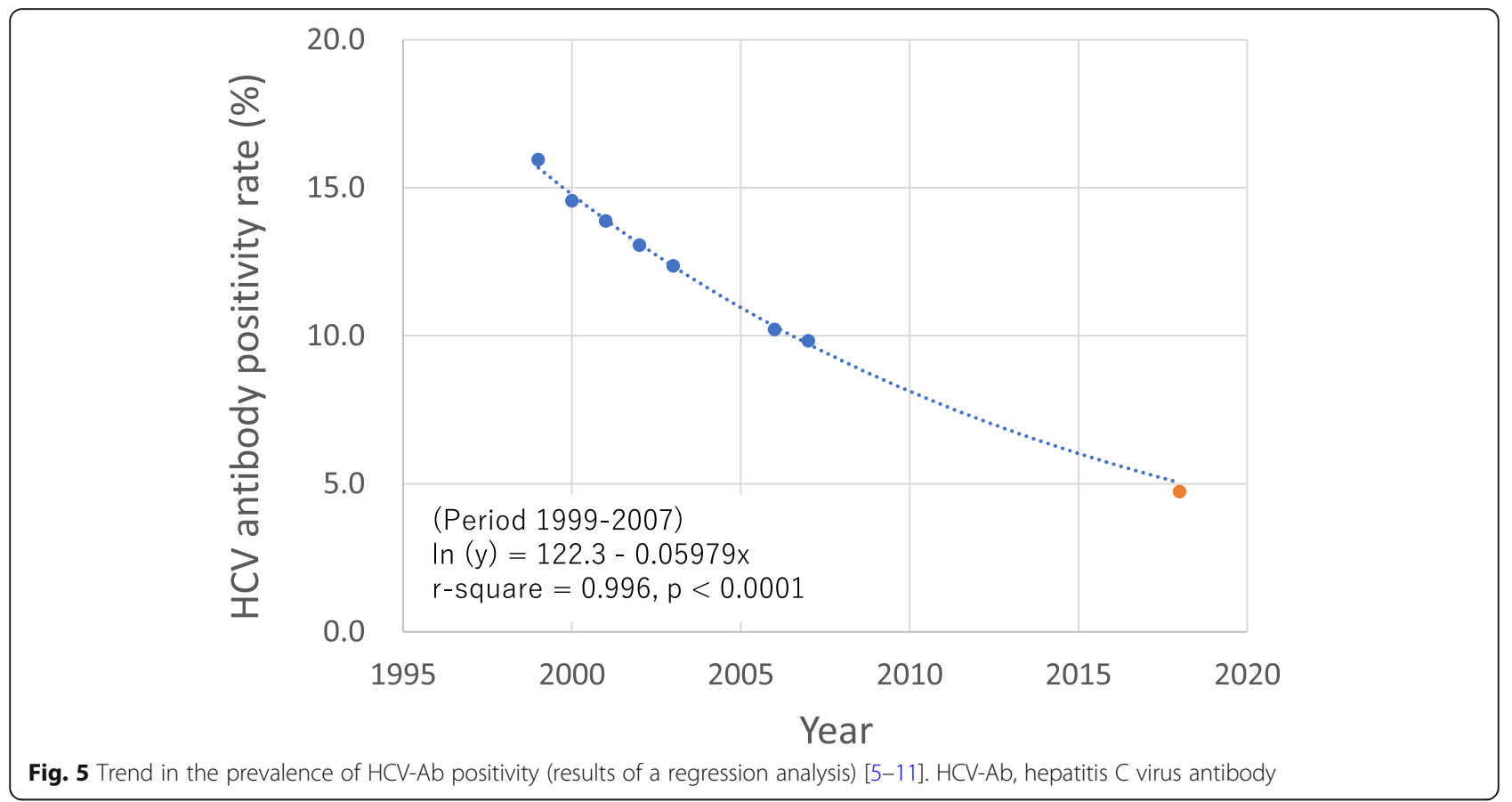

\section{Age and the prevalence of HCV-Ab positivity}

Table 4 shows the relationship between the patients' age and the prevalence of HCV-Ab positivity in the current survey. Similar to the prevalence of HBsAg positivity, in patients between the ages of 60 and 74, the prevalence of $\mathrm{HCV}-\mathrm{Ab}$ positivity was highest.

\section{Treatment method and the prevalence of HCV-Ab positivity}

Table 5 shows the relationship between the patients' treatment methods and the prevalence of $\mathrm{HCV}-\mathrm{Ab}$ positivity in the current survey. The prevalence of HCV-Ab positivity was highest among blood adsorption dialysis

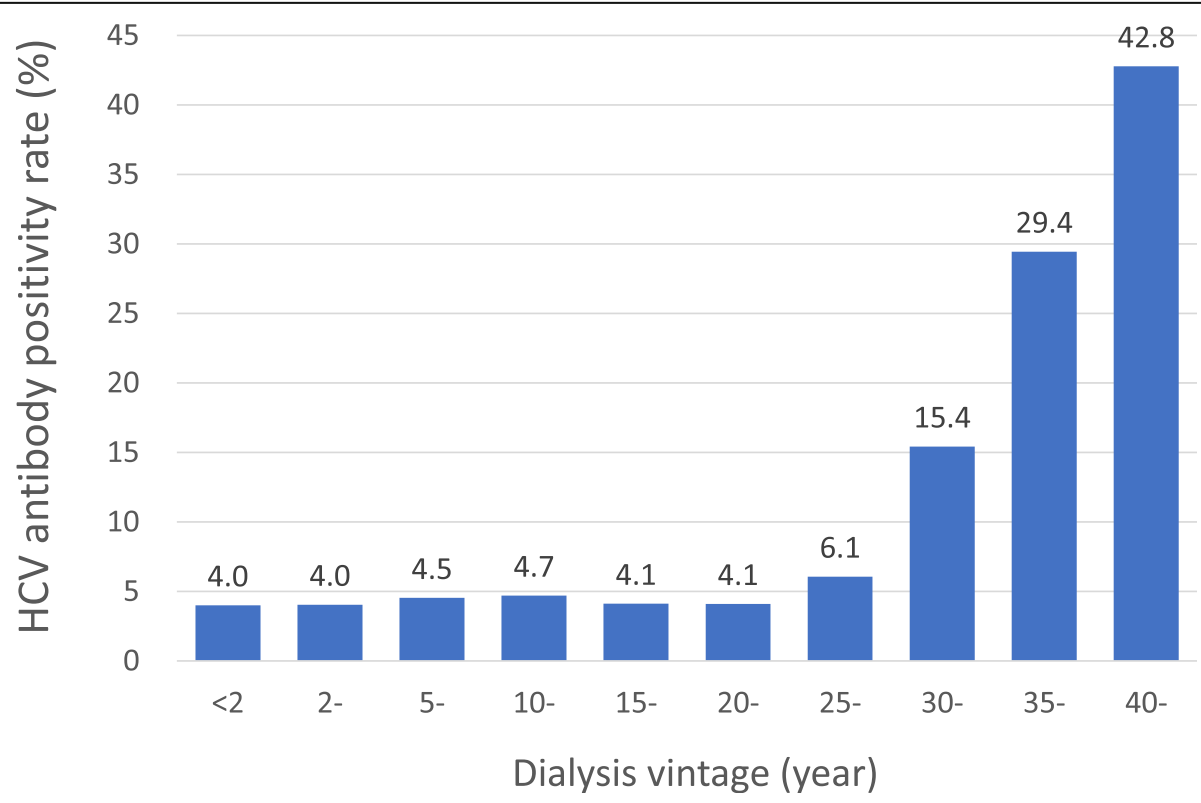

Fig. 6 Prevalence of HCV-Ab positivity according to dialysis vintage as of the end of 2018. The data were obtained from the patient survey. HCVAb, hepatitis $C$ virus antibody 
Table 4 The prevalence of HCV antibody-positive patients sorted by their age, at the end of 2018

\begin{tabular}{|c|c|c|c|c|c|c|c|}
\hline $\begin{array}{l}\text { Age (years } \\
\text { old) }\end{array}$ & $\begin{array}{l}\text { HCV antibody- } \\
\text { negative }\end{array}$ & $\begin{array}{l}\text { HCV antibody- } \\
\text { positive }\end{array}$ & Subtotal & Unspecified & $\begin{array}{l}\text { No data } \\
\text { available }\end{array}$ & Total & $\begin{array}{l}\text { HCV antibody positivity rate } \\
\text { (\%) }\end{array}$ \\
\hline$<15$ & 47 & 0 & 47 & 11 & 30 & 88 & 0.00 \\
\hline $15 \leq,<30$ & 655 & 5 & 660 & 24 & 161 & 845 & 0.76 \\
\hline $30 \leq,<45$ & 9856 & 139 & 9995 & 358 & 1792 & 12,145 & 1.39 \\
\hline $45 \leq,<60$ & 46,430 & 1954 & 48,384 & 1777 & 8535 & 58,696 & 4.04 \\
\hline $60 \leq,<75$ & 108,983 & 6145 & 115,128 & 4079 & 20,628 & $\begin{array}{l}139 \\
835\end{array}$ & 5.34 \\
\hline $75 \leq,<90$ & 84,163 & 4275 & 88,438 & 3305 & 16,485 & $\begin{array}{l}108 \\
228\end{array}$ & 4.83 \\
\hline $90 \leq$ & 5799 & 216 & 6015 & 244 & 1240 & 7499 & 3.59 \\
\hline Subtotal & 255,933 & 12,734 & 268,667 & 9798 & 48,871 & $\begin{array}{l}327 \\
336\end{array}$ & 4.74 \\
\hline Unspecified & 0 & 0 & 0 & 0 & 0 & 0 & \\
\hline $\begin{array}{l}\text { No data } \\
\text { available }\end{array}$ & 0 & 0 & 0 & 0 & 0 & 0 & \\
\hline Total & 255,933 & 12,734 & 268,667 & 9798 & 48,871 & $\begin{array}{l}327 \\
336\end{array}$ & 4.74 \\
\hline Mean & 69 & 70 & 69 & 69 & 69 & 69 & \\
\hline S.D. ${ }^{a}$ & 13 & 11 & 12 & 13 & 13 & 13 & \\
\hline
\end{tabular}

The data were obtained from the patient survey

${ }^{\text {a }}$ Standard deviation

HCV hepatitis $C$ virus

patients (18.04\%). The second highest prevalence of HCV-Ab positivity was among hemodiafiltration patients (4.92\%). The prevalence of HCV-Ab positivity among hemodialysis patients (4.62\%) was slightly lower than that among hemodiafiltration patients. The prevalence of HCV-Ab positivity among patients undergoing peritoneal dialysis $(2.45 \%)$ was much lower than that among patients undergoing hemodialysis. The prevalence of $\mathrm{HCV}-\mathrm{Ab}$ positivity among home hemodialysis patients $(1.84 \%)$ was even lower than that among peritoneal dialysis patients. The prevalence of $\mathrm{HCV}-\mathrm{Ab}$ positivity among hemofiltration patients was $0.0 \%$. Since the

Table 5 The prevalence of HCV antibody-positive patients sorted by their treatment method, at the end of 2018

\begin{tabular}{|c|c|c|c|c|c|c|c|}
\hline Treatment method & $\begin{array}{l}\text { HCV antibody- } \\
\text { negative }\end{array}$ & $\begin{array}{l}\text { HCV antibody- } \\
\text { positive }\end{array}$ & Subtotal & Unspecified & $\begin{array}{l}\text { No data } \\
\text { available }\end{array}$ & Total & $\begin{array}{l}\text { HCV antibody positivity } \\
\text { rate }(\%)\end{array}$ \\
\hline Hemodialysis & 152,905 & 7413 & 160,318 & 5205 & 28,956 & $\begin{array}{l}194 \\
479\end{array}$ & 4.62 \\
\hline Hemodiafiltration & 95,677 & 4946 & 100,623 & 4147 & 16,864 & $\begin{array}{l}121 \\
634\end{array}$ & 4.92 \\
\hline Hemofiltration & 8 & 0 & 8 & 2 & 2 & 12 & 0.00 \\
\hline $\begin{array}{l}\text { Blood adsorption } \\
\text { dialysis }\end{array}$ & 995 & 219 & 1214 & 40 & 180 & 1434 & 18.04 \\
\hline Home hemodialysis & 533 & 10 & 543 & 20 & 145 & 708 & 1.84 \\
\hline Peritoneal dialysis & 5815 & 146 & 5961 & 384 & 2724 & 9069 & 2.45 \\
\hline Subtotal & 255,933 & 12,734 & 268,667 & 9798 & 48,871 & $\begin{array}{l}327 \\
336\end{array}$ & 4.74 \\
\hline $\begin{array}{l}\text { Unspecified/no data } \\
\text { available }\end{array}$ & 0 & 0 & 0 & 0 & 0 & 0 & \\
\hline Total & 255,933 & 12,734 & 268,667 & 9798 & 48,871 & $\begin{array}{l}327 \\
336\end{array}$ & 4.74 \\
\hline
\end{tabular}

The data were obtained from the patient survey HCV hepatitis $C$ virus 
number of hemofiltration patients was very small (only 12), the prevalence of $\mathrm{HCV}-\mathrm{Ab}$ positivity observed in this survey should be interpreted with caution.

\section{HCV-Ab and HCV-RNA}

The HCV-RNA test is a test that measures the presence/ absence of hepatitis $C$ virus antigen. Figure 7 shows the results of the distribution of HCV-Ab and HCV-RNA among the 90,023 patients who underwent both measurements in the current survey (Supplementary Table 5). The results revealed that $92.6 \%$ of the patients tested negative for both HCV-Ab and HCV-RNA, while 2.7\% tested positive for both.

In the 8-year period from 1999 to 2018, both HCV-Ab and HCV-RNA were measured. Figure 8 shows the trend in the prevalence of HCV-RNA positivity among HCV-Ab-positive patients in each of those 8 years [511] (Supplementary Table 3). The rate rose steadily each year until 2003 and then began to decrease from 2006.

\section{ALT (GPT)}

Figure 9 shows the data regarding the serum ALT level in HBsAg-positive and HBsAg-negative patients (Supplementary Table 6), while Fig. 10 shows the data regarding the serum ALT level in HCV-Ab-positive and HCV-Abnegative patients (Supplementary Table 7). Figure 11 shows the data regarding the serum ALT level in HCVRNA-positive and HCV-RNA-negative patients in the HCV-Ab-positive group (Supplementary Table 8).
The serum ALT level was less than $30 \mathrm{IU} / \mathrm{L}$ in most of the above groups of patients.

\section{Discussion}

Trend in the prevalence of HBsAg positivity

Within the framework of this survey program of our society, HBsAg determination was first performed in 1971. In that investigation, $\mathrm{HBsAg}$ was called "Australia antigen (Au antigen)." This survey represented the first investigation of the epidemiological background of individual patients within the framework of this survey program [12]. According to the report on that survey, the total number of patients undergoing maintenance hemodialysis in Japan was 1994 as of the end of 1971 . Of these patients, 1826 were undergoing hemodialysis using either the Kiil-type or Kolf-type dialyzer. The patients, both males and females, were predominantly from the age group of 26-30 years. Information on Au antigen (HBsAg) collected from 1055 of these patients revealed 103 positive cases and 952 negative cases, corresponding to a prevalence of $\mathrm{HBsAg}$ positivity of 9.76\% [12] (prevalence of Au antigen positivity $=$ number of $\mathrm{Au}$ antigen-positive patients $\div$ [number of $\mathrm{Au}$ antigen-positive patients + number of $\mathrm{Au}$ antigennegative patients]). After the investigation in 1971, the next investigation of HBsAg was conducted 28 years later, in 1999 [5]. The prevalence of HBsAg positivity in 1999 was $2.09 \%$, which was much lower than the rate of $9.76 \%$ recorded in 1971.

From 1999 to 2007, the prevalence of HBsAg positivity remained almost unchanged at about $2 \%$ (Fig. 1). In the

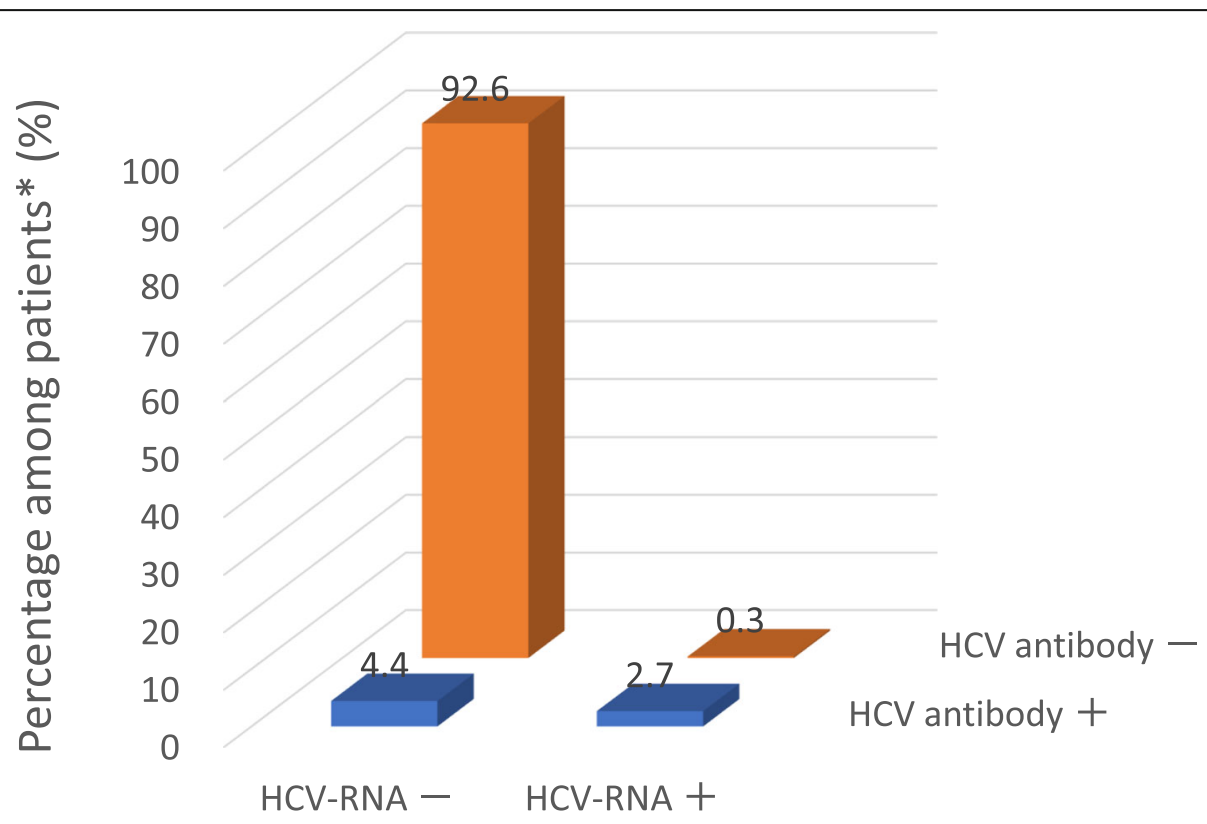

Fig. 7 Prevalence according to HCV-Ab and HCV-RNA statuses as of the end of 2018. The data were obtained from the patient survey. The percentage shows the value among all the patients for whom information on HCV-RNA and HCV-Ab statuses were available. HCV-Ab hepatitis C virus antibody; HCV-RNA hepatitis C virus ribonucleic acid 


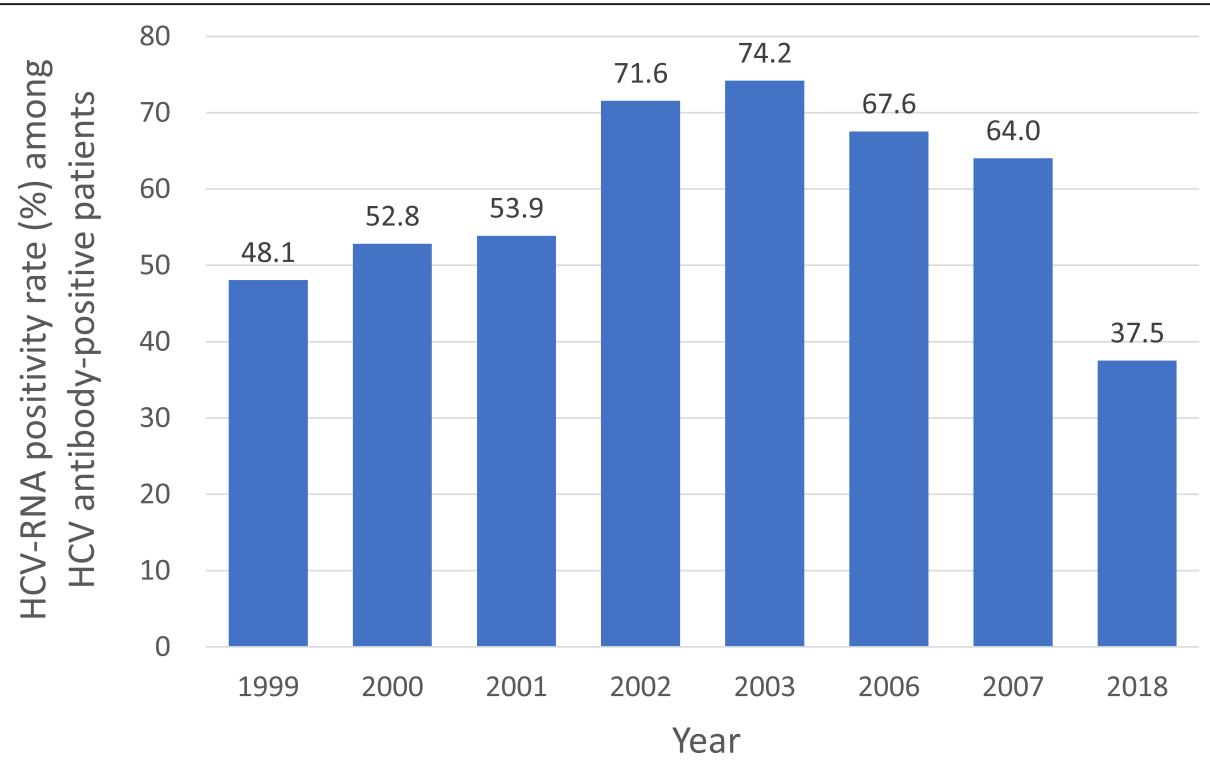

Fig. 8 Trend in the prevalence of HCV-RNA positivity among HCV-Ab-positive patients between 1999 and 2018 [5-11]. HCV-Ab, hepatitis C virus antibody

current survey conducted in 2018, which was 11 years after the last investigation, the prevalence of HBsAg positivity was $1.38 \%$; this prevalence was markedly lower than the last recorded data in 2007. Exponential function regression was performed by plotting the prevalence of HBsAg positivity among all the dialysis patients at 5 time-points during the 1999-2007 period along the $y$ axis and the year along the $x$-axis, and the prevalence of HBsAg positivity (1.38\%) in 2018 was considerably lower than the rate predicted by the regression formula (Fig. 2). This result indicates that the prevalence of $\mathrm{HBsAg}$ positivity among dialysis patients in Japan improved in a non-continuous manner during the 11-year period from
2007 to 2018. The reason for this change remains unexplained. Regarding the general population in Japan, as of the year 2000, the prevalence of HBsAg positivity was reportedly highest (1.37\%) among subjects born between 1946 and 1950 and was lower in other age groups [13]. The cohort born between 1946 and 1950 was aged 50 to 54 years old in 2000. The age of this cohort as of 2018 was 68 to 72 years, which overlaps with the 70-74 age group (which had the highest proportion of positivity among the dialysis patients in the 2018 survey). The prevalence of HBsAg positivity among dialysis patients seems to be higher than the rate in the general population, even as of 2018, although we cannot arrive at a

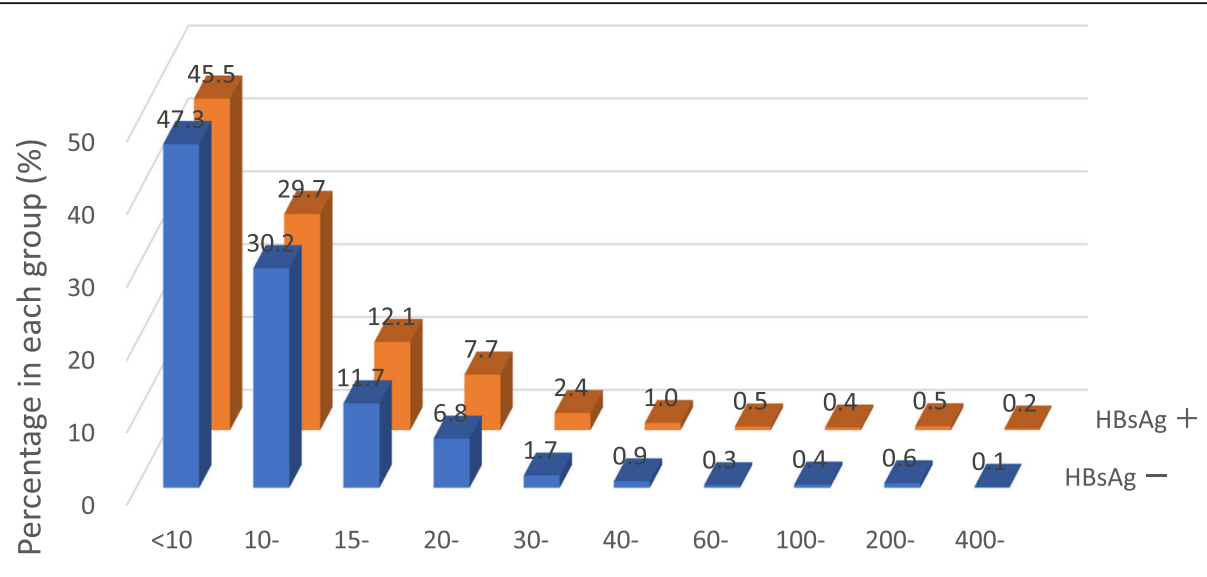

ALT (GPT, IU/L)

Fig. 9 Patient distribution of different ALT (GPT) values according to HBs antigen status as of the end of 2018. The data were obtained from the patient survey. HBsAg, hepatitis B surface antigen 


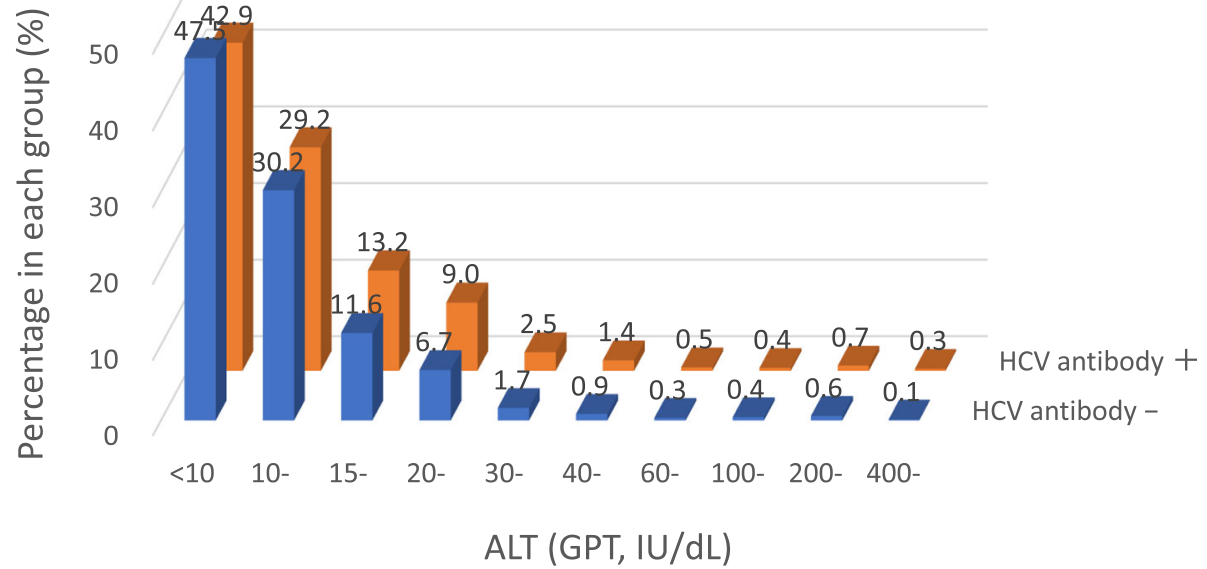

Fig. 10 Patient distribution of different ALT (GPT) values according to HCV-Ab status as of the end of 2018. The data were obtained from the patient survey. HBsAg, hepatitis B surface antigen

definitive conclusion about this tendency because of variances in the age distributions and years of investigation.

\section{Dialysis vintage and the prevalence of HBsAg positivity}

An analysis of the relationship between the dialysis vintage and the prevalence of HBsAg positivity revealed that the prevalence of HBsAg positivity was lowest in the group with a dialysis vintage of less than 2 years, with the rate increasing steadily with increases in the dialysis vintage thereafter (Fig. 3). Figure 12 graphically represents the relationship between the dialysis vintage and the prevalence of HBsAg positivity in the 2007 survey, enabling a comparison of the 2007 survey data with the data from the current survey [9] (Supplementary Table 9). Overall, the prevalence of positivity was higher in 2007 than in 2018. However, the results of the 2007 survey revealed that the prevalence of positivity increased gradually as the dialysis vintage increased, similar to the tendency observed in the 2018 survey.

The group of patients covered in the 2007 survey had started receiving maintenance dialysis in or before 2007 . The group of patients with a dialysis vintage of 10 years or longer covered in the 2018 survey was initiated on maintenance dialysis beginning in or before 2008. These two groups of patients may thus be considered as constituting approximately the same cohort. A comparison of the prevalences of HBsAg positivity in the 2007 and 2018 surveys,

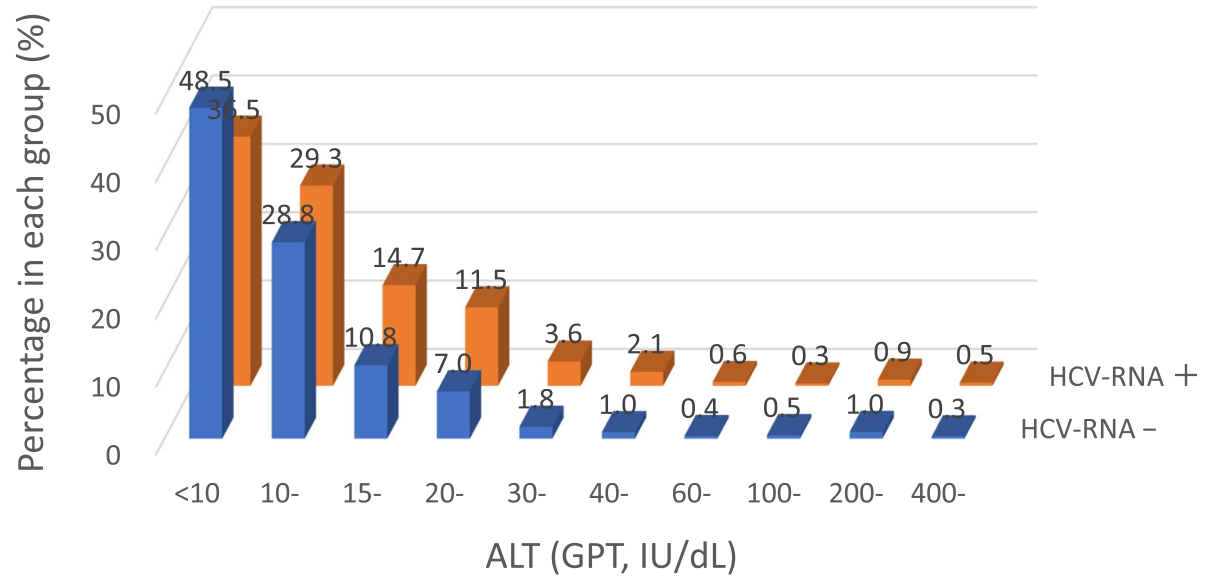

Fig. 11 Patient distribution of different ALT (GPT) values according to HCV-RNA status among HCV-Ab-positive patients as of the end of 2018. The data were obtained from the patient survey. HCV-Ab, hepatitis C virus antibody; HCV-RNA, hepatitis $C$ virus ribonucleic acid 


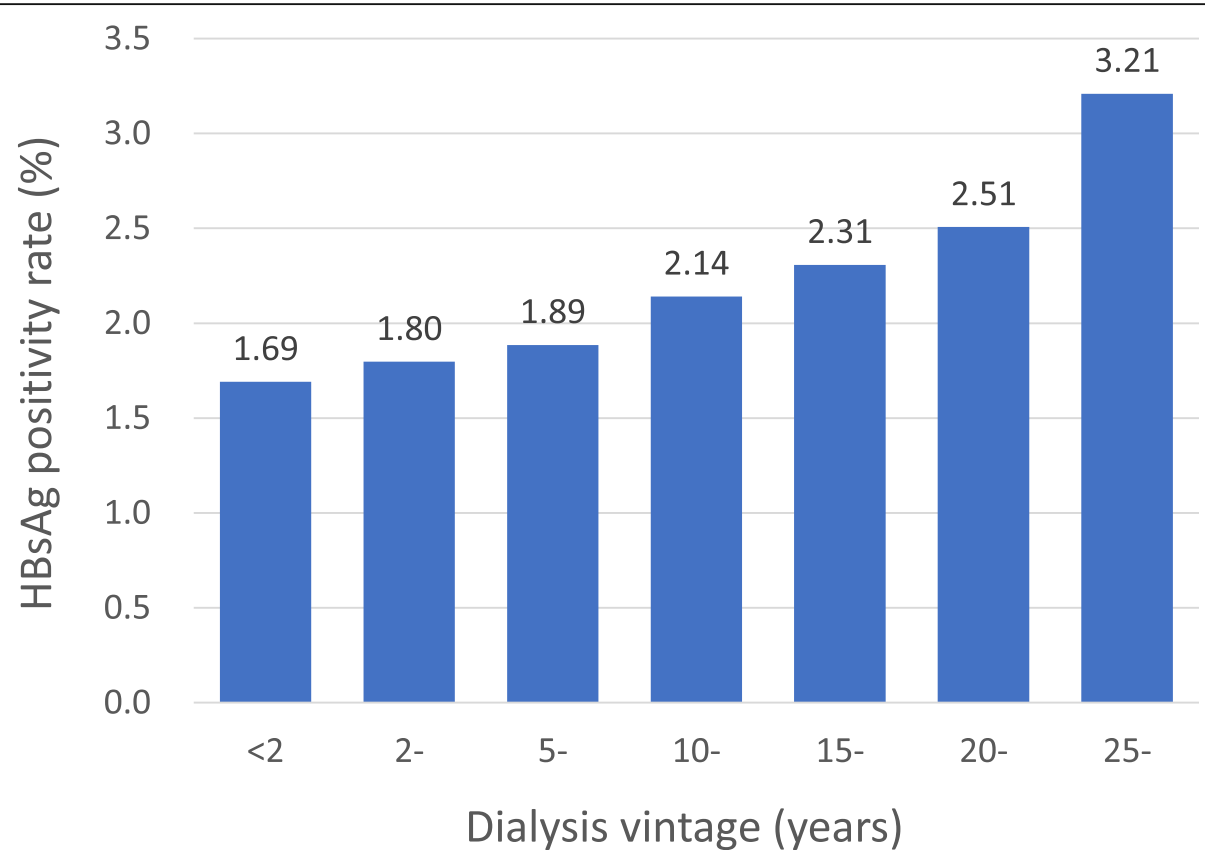

Fig. 12 Prevalence of HBs antigen-positive patients according to dialysis vintage as of the end of 2007. The data were obtained from the patient survey. HBsAg, hepatitis B surface antigen

paying close attention to the aforementioned patient cohort, revealed that the prevalence of positivity in the 2018 survey was lower than that in the 2007 survey. This trend was more marked among patients with a longer dialysis vintage. In other words, the prevalence of positivity in the group of patients with a dialysis vintage of $10-25$ years in the 2018 survey accounted for $85 \%$ of the prevalence of positivity in the group of patients with a dialysis vintage of 0-15 years in the 2007 survey. These two groups of patients constitute approximately the same patient cohort. The prevalence of positivity in the group of patients with a dialysis vintage of 40 years or more in the 2018 survey accounted for about $63 \%$ of the prevalence of positivity in the group of patients with a dialysis vintage of 30 years or more in the 2007 survey. These two groups also constituted approximately the same patient cohort. These results may be interpreted as suggesting a tendency towards seroconversion (from $\mathrm{HBsAg}$-positive to $\mathrm{HBsAg}$-negative) or dropout because of death during the 10-year interval between the two surveys.

In the survey conducted in 2018, the group of patients with a dialysis vintage of less than 10 years (who were initiated on maintenance dialysis in or after 2009) showed a tendency towards a gradual increase in the prevalence of HBsAg positivity as the dialysis vintage increased (Fig. 3). This suggests that, even at present, a certain number of patients newly develop hepatitis B infection after the initiation of hemodialysis.

\section{Age and the prevalence of $\mathrm{HBsAg}$ positivity}

In patients between the ages of 65 and 74 years, the prevalence of $\mathrm{HBsAg}$ positivity was highest. This result may be related to the tendency of the patients between the ages of 65 and 74 years to have a longest dialysis vintage (Supplementary Table 10).

\section{Treatment method and the prevalence of $\mathrm{HBsAg}$ positivity}

The prevalence of HBsAg positivity was highest among hemofiltration patients. However, the number of hemofiltration patients was very small (only 12), so this value should be interpreted with caution. The prevalence of HBsAg positivity among blood adsorption dialysis patients was second highest. This result may be related to these patients having very long dialysis vintages (Supplementary Table 11). Of note, the prevalence of HBsAg positivity among hemodiafiltration patients was lower than that among hemodialysis patients, even though the dialysis vintage of the hemodiafiltration patients tended to be longer than that of the hemodialysis patients. The dialysis vintage of peritoneal dialysis patients is considerably shorter than that of hemodialysis patients. However, the prevalence of $\mathrm{HBsAg}$ positivity among peritoneal dialysis patients was nearly equal to that among hemodialysis patients, even though peritoneal dialysis patients do not require extracorporeal circulation. 


\section{Trend in the prevalence of HCV-Ab positivity}

When an exponential function regression analysis was conducted, with the prevalence of $\mathrm{HCV}-\mathrm{Ab}$ positivity recorded at 7 time-points during the 1999-2007 period plotted along the $y$-axis and the year plotted along the $x$ axis, the prevalence of $\mathrm{HCV}-\mathrm{Ab}$ positivity tended to decrease steadily over time, and the reported prevalence of HCV-Ab positivity in 2018 (4.7\%) was approximately equal to the rate predicted by the regression curve (Fig. 5). This finding may be interpreted as suggesting that the prevalence of $\mathrm{HCV}-\mathrm{Ab}$ positivity among all dialysis patients has continued to decrease at an approximately constant pace during the past 2 decades. However, we cannot rule out the possibility that this interpretation is erroneous for the reason discussed in the next section.

\section{Dialysis vintage and the prevalence of HCV-Ab positivity}

When the prevalence of $\mathrm{HCV}-\mathrm{Ab}$ positivity was analyzed according to dialysis vintage, the prevalence of positivity remained almost unchanged at $4.0-4.7 \%$ when the dialysis vintage was less than 25 years, but the prevalence of positivity increased linearly as the dialysis vintage increased after 25 years (Fig. 6). The year 1993 was 25 years before 2018. The result mentioned above suggests that the prevalence of $\mathrm{HCV}-\mathrm{Ab}$ positivity did not increase with time among the patients who began receiving maintenance dialysis around or after 1993. As reference data, Fig. 13 shows the relationship between the dialysis vintage and the prevalence of $\mathrm{HCV}-\mathrm{Ab}$ positivity in the previous survey performed in 2007 [9] (Supplementary Table 12). In the survey conducted in 2007, the prevalence of positivity remained almost unchanged at 7.6-7.9\% among patients with a dialysis vintage of less than 15 years, but it increased linearly as the dialysis vintage increased beyond 15 years. The year 1992 was 15 years before 2007. This result also suggests that the prevalence of $\mathrm{HCV}-\mathrm{Ab}$ positivity did not increase among the patients who began receiving maintenance dialysis around or after 1992. Hepatitis C virus was discovered in 1989. After the discovery of this virus, the incidence of hepatitis $\mathrm{C}$ associated with blood transfusion decreased sharply $[14,15]$. The treatment of renal anemia using an erythropoietin preparation in dialysis patients began to be covered by the national health insurance program in Japan in 1990 and transfusion therapy for anemia in dialysis patients decreased sharply thereafter. Consequently, the decrease in the prevalence of HCVAb positivity after the year 1992 or 1993 could be interpreted as reflecting these improvements in the treatment of anemia in dialysis patients.

As described in the section on HBsAg, the group of patients with a dialysis vintage of 10-24 years covered by the 2018 survey can be considered being approximately equivalent to the group of patients with a dialysis vintage of $0-14$ years covered by the 2007 survey. The prevalence of HCV-Ab positivity in this group was $4.1-$ $4.7 \%$ in the 2018 survey, which was about $2 / 3$ of the rate of $7.6-7.8 \%$ estimated in the corresponding group in the 2007 survey. In general, patients are unlikely to test negative for HCV-Ab once they have tested positive. Here, we may assume that the low prevalence of $\mathrm{HCV}$ $\mathrm{Ab}$ positivity in the current survey can be attributed to a reduction in $\mathrm{HCV}-\mathrm{Ab}$-positive patients because of death. If this assumption is valid, the prevalence of positivity

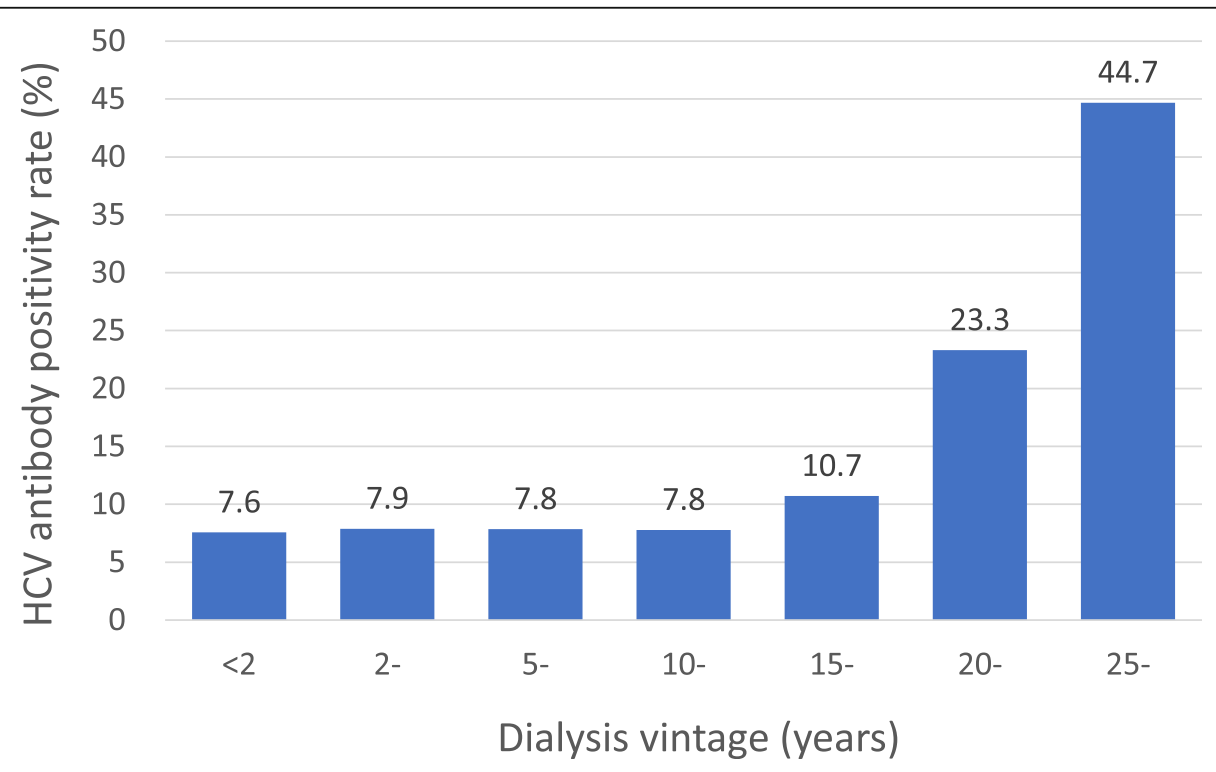

Fig. 13 Prevalence of HCV-Ab positivity among patients according to dialysis vintage as of the end of 2007. The data were obtained from the patient survey. HCV-Ab, hepatitis C virus antibody 
could be considered as showing a tendency towards a gradual reduction with increasing dialysis vintage. However, the survey results did not indicate such a trend. Furthermore, the prevalence of positivity in the group of patients with a dialysis vintage of less than 10 years was also $4.0-4.5 \%$, which was approximately equal to the rate in the patient group with a dialysis vintage of 10-24 years. We may therefore judge that the dropout of $\mathrm{HCV}-\mathrm{Ab}$-positive patients because of death was not responsible for the lower prevalence of HCV-Ab positivity in the current survey in the group of patients that was initiated on dialysis in or after 1992-1993, compared with the prevalence of positivity documented in the same group in the previous survey conducted in 2007. The reason for the lower prevalence of HCV-Ab positivity in the current survey, compared with that in the 2007 survey, remains uncertain. One potential explanation is that the methods used for HCV-Ab testing have changed during the last decade. HCV antibody testing methods can be classified into three generations (first, second, and third) depending on the region of the viral antigen used for antibody detection. Later generations of testing methods detect a wider range of antigens. The latest 3rd generation inspection methods were developed in the late 1990s, and these 3rd generation inspection methods became widespread in the 2000s. In general, the difference in detection sensitivity between the 2nd generation test method and the 3rd generation test method for HCV antibody is thought to be minimal [16]. However, the difference between the prevalence of $\mathrm{HCV}-\mathrm{Ab}$ positivity in the 2007 survey and that in the 2018 survey may partly reflect the difference in detection sensitivity between 2nd generation and 3rd generation HCV antibody test methods.

As mentioned in the preceding section, the prevalence of $\mathrm{HCV}-\mathrm{Ab}$ positivity among all dialysis patients included in the 2018 survey was approximately equal to the rate predicted from the changes over time for the prevalence of $\mathrm{HCV}-\mathrm{Ab}$ positivity during the 1999-2007 period. If we assume that the prevalence of HCV-Ab positivity at present is, for some reason or other, equivalent to about $2 / 3$ of the prevalence of $\mathrm{HCV}-\mathrm{Ab}$ positivity recorded with the testing method available in 2007, the prevalence of positivity in 2018 as predicted based on the changes over time during the 1999-2007 period should be about $2 / 3$ of the predicted value, i.e., equal to about $3 \%$. In practice, however, the prevalence of positivity recorded in 2018 was $4.7 \%$. This could be interpreted as suggesting that the magnitude of the reduction in the prevalence of $\mathrm{HCV}-\mathrm{Ab}$ positivity among dialysis patients overall in the 2018 survey was not as large as the reduction predicted by the changes in the prevalence of HCVAb positivity during the $1999-2007$ period.

\section{Age and the prevalence of HCV-Ab positivity}

Similar to the prevalence of HBsAg positivity, in patients between the ages of 65 and 74 years, the prevalence of HCV-Ab positivity was highest. This result may be related to the tendency of the patients between the ages of 65 and 74 years to have a longest dialysis vintage (Supplementary Table 10).

\section{Treatment method and the prevalence of HCV-Ab positivity}

The prevalence of $\mathrm{HCV}-\mathrm{Ab}$ positivity was extremely high among patients undergoing blood adsorption dialysis. This observation is probably related to the very long dialysis vintages of these patients, since the prevalence of $\mathrm{HCV}-\mathrm{Ab}$ positivity was significantly higher among patients with a dialysis vintage of over 25 years (Fig. 6, Supplementary Table 4). Of note, unlike the prevalence of $\mathrm{HBsAg}$ positivity, the prevalence of $\mathrm{HCV}-\mathrm{Ab}$ positivity in peritoneal dialysis patients was much lower than the prevalence of $\mathrm{HCV}-\mathrm{Ab}$ positivity among hemodialysis patients. The dialysis vintage of peritoneal dialysis patients is considerably shorter than that of hemodialysis patients. And as mentioned before, the prevalence of $\mathrm{HCV}-\mathrm{Ab}$ positivity increased much more than that of HBsAg positivity along with the dialysis vintage. These situations may have affected the difference in the prevalences of HCV-Ab and HBsAg positivity among the patients.

\section{HCV-Ab and HCV-RNA}

An analysis of the distribution of HCV-Ab and HCVRNA among dialysis patients revealed that $92.6 \%$ of the patients tested negative for both $\mathrm{HCV}-\mathrm{Ab}$ and $\mathrm{HCV}$ RNA, while $2.7 \%$ tested positive for both (Fig. 7). As reference data, Fig. 14 shows the distribution of HCV-Ab and HCV-RNA in the survey conducted in 2007 (analyzing 63, 098 patients; Supplementary Table 13). In 2007, 85.6\% of the patients tested negative for both HCV-Ab and HCVRNA, while $9.0 \%$ tested positive for both. Thus, the negativity rate for both antibody and RNA was 7.0 percentage points higher in 2018 than in 2007, while the prevalence of positivity for both was 6.3 points lower in 2018 than in 2007. Thus, one can say that the prevalence of positivity for both antibody and RNA had decreased in 2018 to 1/3 or lower, compared with the rate recorded in 2007. For a long time, no treatment was available for dialysis patients with hepatitis C. In 2015, however, treatment with directacting antivirals (DAAs) began to be covered by the national health insurance program in Japan. At present, the treatment of hepatitis $C$ using DAAs in dialysis patients is also covered by the national health insurance program. The clinical use of DAAs for the treatment of hepatitis C may have contributed to the sharp drop in the percentage of patients who tested positive for both $\mathrm{HCV}-\mathrm{Ab}$ and 


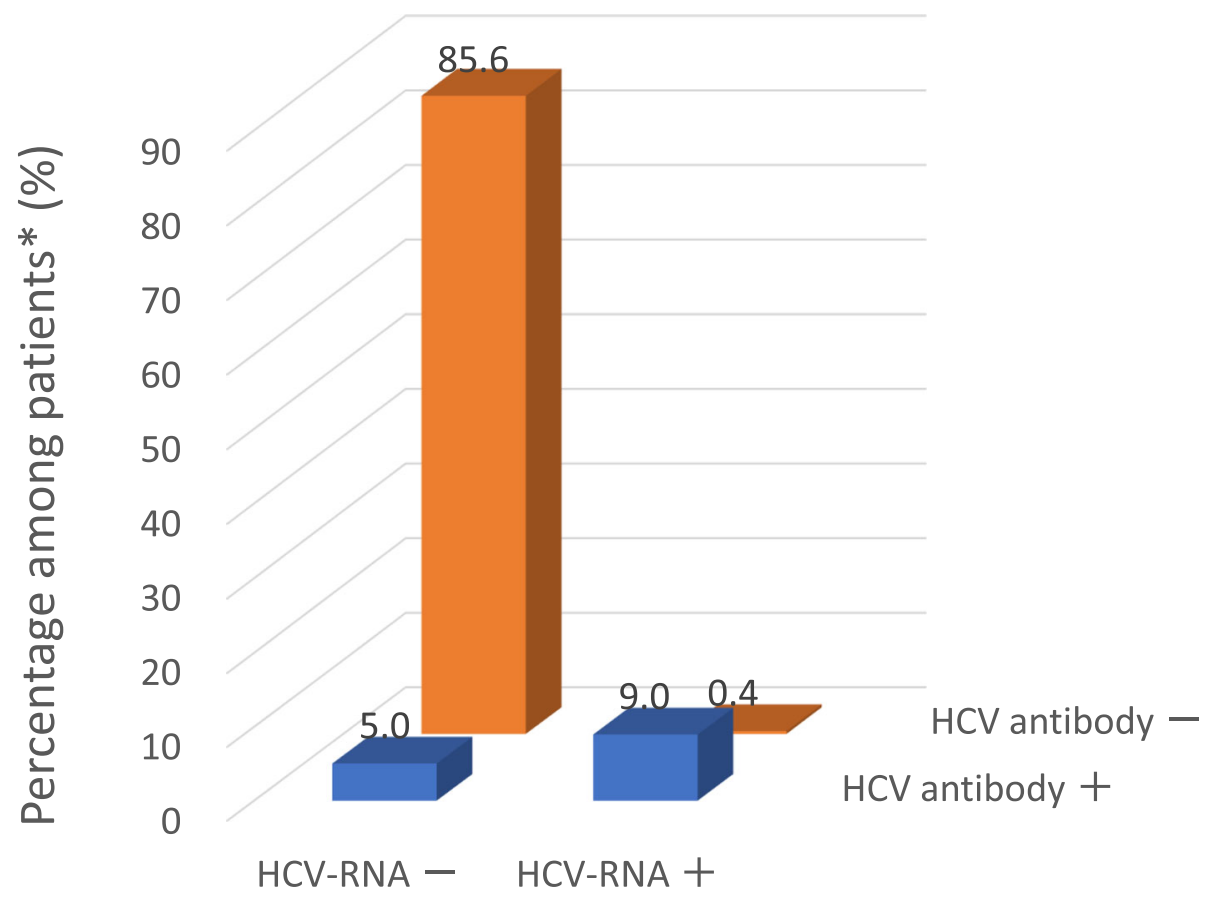

Fig. 14 Prevalence according to HCV-Ab and HCV-RNA statuses as of the end of 2007. The data were obtained from the patient survey. The percentage shows the value among all the patients for whom information on HCV-RNA and HCV-Ab statuses were available. HCV-Ab, hepatitis C virus antibody; HCV-RNA, hepatitis $C$ virus ribonucleic acid

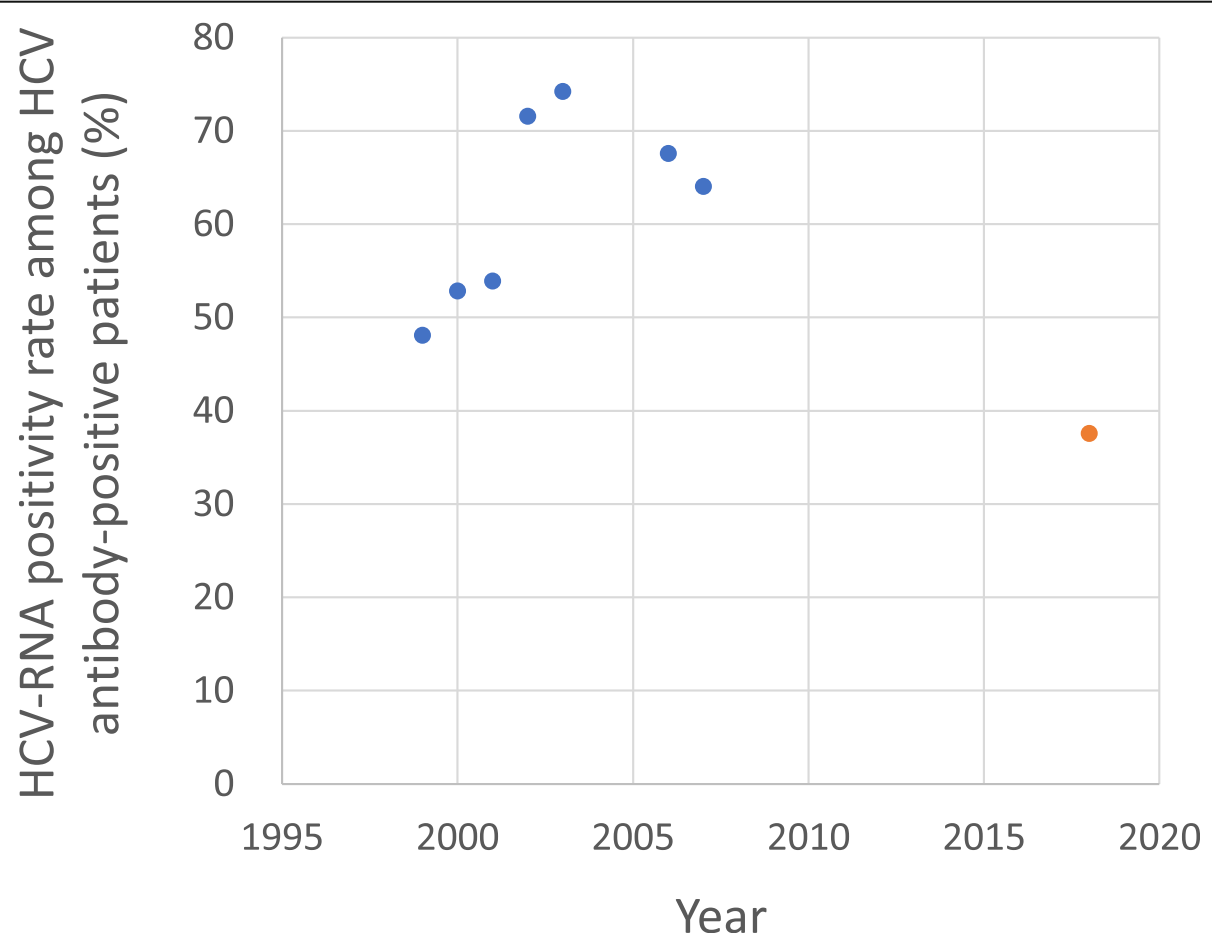

Fig. 15 Trend in the prevalences of HCV-RNA positivity among HCV-Ab-positive patients (using a proportional scale showing the history year). The data were obtained from the patient survey. HCV-Ab, hepatitis C virus antibody; HCV-RNA, hepatitis C virus ribonucleic acid 
HCV-RNA during the 11-year period from 2007 to 2018. To test the validity of this hypothesis, we conducted the following analysis.

In the current survey, HCV-RNA data was available for $50.2 \%$ of the HCV-Ab-positive patients, while similar data was available for only $32.7 \%$ of the HCV-Ab-negative patients. These results suggest that HCV-RNA measurements are less likely to be conducted for HCV-Abnegative patients. Thus, the difference in the percentage of patients who have undergone HCV-RNA testing among HCV-Ab-negative patients might have caused a bias in the prevalence of HCV-RNA positivity. In other words, if the percentage of patients undergoing HCV-RNA determination among the HCV-Ab-negative patients increased, the number of HCV-RNA-negative patients would also increase, causing a bias (reduction) in the prevalence of HCV-RNA positivity among all the patients. To avoid such a bias, we calculated the prevalence of HCV-RNA positivity among the HCV-Ab-positive patients alone in each survey year and analyzed the changes over time during the 8-year period in which the HCV-Ab and HCVRNA statuses were determined (Fig. 8) [5-11]. The rate increased each year until 2003 but then began to decrease from 2006 onwards. Figure 15 shows a scatter diagram, with the prevalence of HCV-RNA positivity plotted along the $y$-axis and the year plotted along the $x$-axis. Because a tendency towards a reduction in the prevalence of $\mathrm{HCV}$ RNA positivity began to be noted in 2006, it was difficult to judge based on this illustration alone whether the prevalence of positivity in 2018 was lower than the rate anticipated from the trend noted before 2007, i.e., whether the start of the clinical application of DAAs in 2015 caused a decrease in the number of HCV-RNA-positive patients.

\section{ALT (GPT)}

An analysis of the serum ALT level in HBsAg-positive and HBsAg-negative patients revealed that the mean serum ALT level was slightly lower in the HBsAg-negative patients $(14.57 \mathrm{IU} / \mathrm{L})$ than in the HBsAg-positive patients (15.49 IU/L); however, large differences in the distribution of patients with low and high serum ALT levels were not seen between the two groups (Fig. 9). In a similar analysis of the serum ALT level conducted among HCV-Abpositive and $\mathrm{HCV}$-Ab-negative patients, the mean serum ALT level was slightly lower in the HCV-Ab-negative patients $(14.51 \mathrm{IU} / \mathrm{L})$ than in the HCV-Ab-positive patients (16.36 IU/L), although large differences in the distribution of patients with high and low serum ALT levels were not seen between the two groups (Fig. 10). These results indicate that neither the HBsAg status nor the HCV-Ab status exerted a significant impact on the serum ALT level in dialysis patients.
When the serum ALT levels in HCV-RNA-positive and HCV-RNA-negative patients were analyzed only among HCV-Ab-positive patients, the mean level was higher in the HCV-RNA-positive patients (19.09 IU/L) than in the HCV-RNA-negative patients (16.60 IU/L), and an analysis of the patient distribution revealed a lower percentage of patients with a serum ALT level of less than $10 \mathrm{IU} / \mathrm{L}$ and a higher percentage of patients with a serum ALT level in the range of 15-59 IU/L in the HCV-RNA-positive group, compared with the HCVRNA-negative group (Fig. 11). These findings indicate that seropositivity for HCV-RNA among the HCV-Abpositive patients tended to be associated with hepatic impairment.

\section{Conclusion}

Among the dialysis patients in Japan, the prevalence of HBsAg positivity was $1.38 \%$ and the prevalence of HCV$\mathrm{Ab}$ positivity was $4.7 \%$ as of the end of 2018 . Each of these rates was markedly lower than the corresponding rate $(9.8 \%$ and $4.7 \%$, respectively) reported in the 2007 survey. The percentage of HCV-RNA-positive patients among all the HCV-Ab-positive patients was 37.5\%, which was also much lower than the rate of $64.0 \%$ estimated in 2007. The prevalence of HBsAg positivity tended to be higher in patients with a longer dialysis vintage. The prevalence of HCV-Ab positivity was not correlated with the dialysis vintage when the dialysis vintage was less than 30 years, but it tended to increase as the dialysis vintage increased after 30 years.

\section{Abbreviations}

ALT: Alanine aminotransferase; Au antigen: Australia antigen; DAAs: Directacting antivirals; GPT: Glutamic pyruvic transaminase; HBsAg: Hepatitis B surface antigen; HCV: Hepatitis C virus; JRDR: The JSDT Renal Data Registry; JSDT: Japanese Society for Dialysis Therapy; RNA: Ribonucleic acid;

UMIN: University hospital Medical Information Network

\section{Supplementary Information}

The online version contains supplementary material available at https://doi. org/10.1186/s41100-021-00338-8.

Additional file 1: Supplementary Table 1. Trend in the prevalence of HBs-antigen-positive patients from 1999 to 2018.

Additional file 2: Supplementary Table 2. Prevalence of HBs-antigenpositive patients according to dialysis vintage as of the end of 2018.

Additional file 3: Supplementary Table 3. Trends in the prevalences of HCV-Ab positivity and HCV-RNA positivity from 1999 to 2018.

Additional file 4: Supplementary Table 4. Prevalence of HCV-Ab positivity according to dialysis vintage as of the end of 2018.

Additional file 5: Supplementary Table 5. Prevalence according to HCV-Ab and HCV-RNA statuses as of the end of 2018

Additional file 6: Supplementary Table 6. Patient-distribution of different ALT (GPT) values according to HBs-antigen status as of the end of 2018.

Additional file 7: Supplementary Table 7. Patient-distribution of different ALT (GPT) values according to HCV-Ab status as of the end of 2018. 
Additional file 8: Supplementary Table 8. Patient-distribution of different ALT (GPT) values according to HCV-RNA status among HCV-Abpositive patients as of the end of 2018.

Additional file 9: Supplementary Table 9. Prevalence of HBs-antigenpositive patients according to dialysis vintage as of the end of 2007

Additional file 10: Supplementary Table 10. Dialysis vintage of all dialysis patients according to age as of the end of 2018.

Additional file 11: Supplementary Table 11. Dialysis vintage of all dialysis patients according to treatment method as of the end of 2018.

Additional file 12: Supplementary Table 12. Prevalence of HCV-Ab positivity according to dialysis vintage as of the end of 2007.

Additional file 13: Supplementary Table 13. Prevalence according to HCV-Ab and HCV-RNA statuses as of the end of 2007.

\section{Acknowledgements}

We owe the completion of this survey to the efforts of the members of the subcommittee for JRDR Regional Cooperation, the members of which are mentioned below, and the staff members of the dialysis facilities who participated in the survey and responded to the questionnaires. We would like to express our deepest gratitude to all these people.

Subcommittee for JRDR Regional Cooperation: Kazuyuki Maeno, Tetsuya Kawata, Chikara Oyama, Koji Seino, Toshinobu Sato, Shigeru Sato, Minoru Ito, Junichiro Kazama, Atsushi Ueda, Osamu Saito, Tetsuo Ando, Tomonari Ogawa, Hiroo Kumagai, Hiroyuki Terawaki, Ryoichi Ando, Masaki Abe, Tetsuya Kashiwagi, Chieko Hamada, Yugo Shibagaki, Nobuhito Hirawa, Hisaki Shimada, Yoichi Ishida, Hitoshi Yokoyama, Ryoichi Miyazaki, Mizuya Fukasawa, Yuji Kamijyo, Teppei Matsuoka, Akihiko Kato, Noriko Mori, Yasuhiko Ito, Hirotake Kasuga, Sukenari Koyabu, Tetsuro Arimura, Tetsuya Hashimoto, Masaaki Inaba, Terumasa Hayashi, Tomoyuki Yamakawa, Shinichi Nishi, Akira Fujimori, Tatsuo Yoneda, Shigeo Negi, Akihisa Nakaoka, Takafumi Ito, Hitoshi Sugiyama, Takao Masaki, Yutaka Nitta, Kazuyoshi Okada, Masahito Yamanaka, Masaharu Kan, Kazumichi Ota, Masahito Tamura, Koji Mitsuiki, Yuji Ikeda, Masaharu Nishikido, Akira Miyata, Tadashi Tomo, Shoichi Fujimoto, Tsuyoshi Nosaki, and Yoshinori Oshiro.

\section{Consortia}

On behalf of the Japanese Society for Dialysis Therapy Renal Data Registry Committee:

Kazuyuki Maeno, Tetsuya Kawata, Chikara Oyama, Koji Seino, Toshinobu Sato, Shigeru Sato, Minoru Ito, Junichiro Kazama, Atsushi Ueda, Osamu Saito, Tetsuo Ando, Tomonari Ogawa, Hiroo Kumagai, Hiroyuki Terawaki, Ryoichi Ando, Masaki Abe, Tetsuya Kashiwagi, Chieko Hamada, Yugo Shibagaki, Nobuhito Hirawa, Hisaki Shimada, Yoichi Ishida, Hitoshi Yokoyama, Ryoichi Miyazaki, Mizuya Fukasawa, Yuji Kamijyo, Teppei Matsuoka, Akihiko Kato, Noriko Mori, Yasuhiko Ito, Hirotake Kasuga, Sukenari Koyabu, Tetsuro Arimura, Tetsuya Hashimoto, Masaaki Inaba, Terumasa Hayashi, Tomoyuki Yamakawa, Shinichi Nishi, Akira Fujimori, Tatsuo Yoneda, Shigeo Negi, Akihisa Nakaoka, Takafumi Ito, Hitoshi Sugiyama, Takao Masaki, Yutaka Nitta, Kazuyoshi Okada, Masahito Yamanaka, Masaharu Kan, Kazumichi Ota, Masahito Tamura, Koji Mitsuiki, Yuji Ikeda, Masaharu Nishikido, Akira Miyata, Tadashi Tomo, Shoichi Fujimoto, Tsuyoshi Nosaki, and Yoshinori Oshiro.

\section{Authors' contributions}

$\mathrm{KN}, \mathrm{IM}, \mathrm{MT}$, and SN finalized the results of the survey and prepared the manuscript. SN, NH, and AW designed the survey sheets and created a special program that ran within MS Excel for the convenience of the selfassessments of dialysis quality made by each dialysis facility. T Hase, T Hama, $J H, N J, K M, S G$, and MA were responsible for the data analysis. KY and IM were responsible for the ethics of the JRDR survey. HN was the president of JSDT in 2018, checked all the results from the 2018 JRDR survey, and approved their publication. All the authors have read and approved the final manuscript.

\section{Funding}

The present study did not receive any funding.

All efforts and costs for the 2018 JRDR survey and the creation of the ADR were provided by the JSDT.

\section{Availability of data and materials}

For anyone wishing to use the data and materials from the current manuscript without modifications, all the data and materials are freely available provided that the source of the data (JSDT) is stated.

For anyone wishing to use the data and materials from the current manuscript with modifications, including any re-calculations, etc., the data and materials may be used if the following sentence is included with their publication. "The data reported here were provided by the Japanese Society for Dialysis Therapy (JSDT). The interpretation and reporting of these data are the responsibility of the authors and should in no way be seen as an official policy or interpretation of the JSDT."

\section{Declarations}

\section{Ethics approval and consent to participate}

The JSDT registry was approved by the ethics committee of the JSDT (approval no. 1).

The aims of the JSDT Renal Data Registry (JRDR) were adequately explained to the participating dialysis patients at the dialysis facilities.

Written consent from the patients was not required because all the data had already been collected and no new interventions were performed.

The original data was totally anonymized to avoid any risk of compromising the privacy of the dialysis facilities and the patients.

The data presented in the current manuscript does not contain any images, videos, or voice recordings that could be used to identify an individual.

\section{Consent for publication}

Not applicable

\section{Competing interests}

The authors declare that they have no competing interests.

Received: 8 January 2021 Accepted: 12 April 2021

Published online: 10 May 2021

\section{References}

1. Nakai S. The history of Japanese Society for Dialysis Therapy Registry. J J.jn Soc Dial Ther. 2010;43(2):119-52. (in Japanese). https://doi.org/10.4009/ jsdt.43.119.

2. Masakane I, Nakai S. Recent trends of chronic dialysis in Japan from the viewpoint of the JSDT Renal Data Registry. J Jpn Soc Dial Ther. 2016;49(3): 211-8. (in Japanese). https://doi.org/10.4009/jsdt.49.211.

3. Nitta K, Masakane I, Hanafusa N, Goto S, Abe M, Nakai S, et al. Annual dialysis data report 2018, JSDT Renal Data Registry. J Jap Soc Dial Ther. 2019;52(12):679-754. (in Japanese). https://doi.org/10.4009/jsdt.52.679.

4. Nitta K, Goto S, Masakane I, Hanafusa N, Taniguchi M, Hasegawa T, et al. Annual dialysis data report for 2018, JSDT Renal Data Registry: survey methods, facility data, incidence, prevalence, and mortality. Ren Replace Ther. 2020;6(1):41. https://doi.org/10.1186/s41100-020-00286-9.

5. Nakai S, Shinzato T, Sanaka T, Kikuchi K, Kitaoka T, Shinoda T, et al. An overview of dialysis treatment in Japan (as of Dec. 31, 1999). J Jpn Soc Dial Ther. 2001;34(7):1121-47.

6. Nakai S, Shinzato T, Sanaka T, Kikuchi K, Kitaoka T, Shinoda T, et al. The current state of chronic dialysis treatment in Japan (as of December 31 2000). J Jpn Soc Dial Ther. 2002;35(7):1155-84. https://doi.org/10.4009/jsdt.3 5.1155.

7. Nakai S, Shinzato T, Nagura Y, Masakane I, Kitaoka T, Shinoda T, et al. An overview of regular dialysis treatment in Japan (as of December 2001). Ther Apher Dial. 2004;8(1):3-32. https://doi.org/10.1111/j.1526-0968.2004.00109.x.

8. Nakai S, Masakane I, Akiba T, Shigematsu T, Yamagata K, Watanabe Y, et al. Overview of regular dialysis treatment in Japan as of 31 December 2006. Ther Apher Dial. 2008;12(6):428-56. https://doi.org/10.1111/j.1744-9987.2008. 00634.x.

9. Nakai S, Masakane I, Shigematsu T, Hamano T, Yamagata K, Watanabe $Y$, et al. An overview of regular dialysis treatment in Japan (as of 31 December 2007). Ther Apher Dial. 2009;13(6):457-504. https://doi.org/10.1111/j.1744$9987.2009 .00789 x$

10. Nakai S, Shinzato T, Nagura Y, Masakane I, Kitaoka T, Shinoda T, et al. An overview of regular dialysis treatment in Japan (as of December 2002). Ther Apher Dial. 2004;8(5):358-82. 
11. Nakai S, Shinzato T, Nagura Y, Masakane I, Kitaoka T, Shinoda T, et al. An overview of regular dialysis treatment in Japan as of December 2003. Ther Apher Dial. 2005;9(6):431-58.

12. Odata M. Nationwide questionnaire report on the current status of dialysis in Japan. J Jap Soc Dial Ther. 1972;5(2):184-8 (in Japanese).

13. Akita T, Tanaka J, Satake M, Lin Y, Wada T, Kato K, et al. Meta-regression analysis of sex- and birth year-specific prevalence of HBsAg and anti-HCV among undiagnosed Japanese: Data from the first-time blood donors, periodical health checkup, and the comprehensive health checkup with lifestyle education (Ningen Dock). J Epidemiol. 2019;30(9):420-5. https://doi. org/10.2188/jea.JE20190055.

14. Choo QL, Kuo G, Weiner AJ, Overby LR, Bradley DW, Houghton M. Isolation of a cDNA clone derived from a blood-borne non- $A$, non-B viral hepatitis genome. Science. 1989;244(4902):359-62. https://doi.org/10.1126/science.2 523562.

15. Kuo G, Choo QL, Alter HJ, Gitnick GL, Redeker AG, Purcell RH, et al. An assay for circulating antibodies to a major etiologic virus of human non-A, non-B hepatitis. Science. 1989;244(4902):362-4. https://doi.org/10.1126/science.24 96467.

16. Fujino T, Enjoji M, Yatsuhashi H. Development of assays for measuring HBVand HCV-related markers. J Anal Bio-Sci. 2013;36(5):343-51.

\section{Publisher's Note}

Springer Nature remains neutral with regard to jurisdictional claims in published maps and institutional affiliations.

Ready to submit your research? Choose BMC and benefit from:

- fast, convenient online submission

- thorough peer review by experienced researchers in your field

- rapid publication on acceptance

- support for research data, including large and complex data types

- gold Open Access which fosters wider collaboration and increased citations

- maximum visibility for your research: over $100 \mathrm{M}$ website views per year

At BMC, research is always in progress.

Learn more biomedcentral.com/submissions 